\title{
The Effect of Perceived Cost, Trust, Usefulness and Customer Value Addition on Intention to Use of Go-Pay Mobile Payment Services in Small Merchants
}

\section{Handri Mufti Nirmawan ${ }^{1 *}$,}

Winny Astiwardhani 2,

1,2 Master Program, Binus Business School, Bina Nusantara University, Jakarta, Indonesia

\begin{tabular}{|c|c|}
\hline ARTICLE INFO & ABSTRACT \\
\hline $\begin{array}{l}\text { ISSN: 2723-1097 } \\
\text { Keywords: } \\
\text { Intention to use, Go- } \\
\text { Pay, Perceived cost, } \\
\text { Perceived trust, } \\
\text { Percived customer } \\
\text { value addition }\end{array}$ & $\begin{array}{l}\text { This research is based on the phenomenon of the problem of the widespread use of } \\
\text { payment methods based on financial technology (fintech), namely mobile payments } \\
\text { which contribute to the circulation of electronic money reaching Rp.47.2 trillion in } \\
\text { December 2018. However, there are mental barriers that increasingly hinder the } \\
\text { intention to adopt this fintech-based service. One of the largest providers of mobile } \\
\text { payment is Go-Pay who owned by Go-Jek. These barriers are in the form of costs, } \\
\text { trustworthiness, usefulness, benefits, and experiences that will be obtained. The } \\
\text { points of this review are to recognize the effect of Perceived cost, Perceived trust, } \\
\text { Perceived usefulness, and Perceived customer value addition on Intention to Use } \\
\text { Go-Pay Mobile Payment services on Small merchants. The samples used were } 120 \\
\text { respondents of small merchants. Multiple linear regression analysis used in this } \\
\text { study to identify the relationship between variables. These results indicate that the } \\
\text { perceived cost, perceived trust, and perceived customer value addition have a } \\
\text { significant positive effect on Intention to use, while perceived usefulness has a } \\
\text { negative and insignificant effect on Intention to use. Hope through the research } \\
\text { that has been done, hopefully to provide benefits for mobile payment providers in } \\
\text { developing ways to attract small merchant partners for their mobile payment } \\
\text { facilities. }\end{array}$ \\
\hline
\end{tabular}

\section{Introduction}

Since the financial technology (fintech) emerges, the current mobile payment method is growing, as seen from the Worldwide market share, which increased by 177\% between 2019-2021. (Statista and MDI Ventures \& Mandiri Sekuritas in Warta Ekonomi, 2019). Some of the most famous mobile payment providers in the world are Paypal, Google Wallet, and Alipay. In Indonesia, the most famous mobile payment providers are Go-Pay, OVO, and DANA. The cycle amount of electronic money in Indonesia reached IDR 167.21 million in December 2018 and increased by 85.78\% from the previous year on an average growth of $45 \%$ over the past five years and a nominal value of IDR 47.2 trillion (Bank Indonesia in CNBC, 2019) with Go-Pay being the leading provider of the mobile payment market share with almost three quarters of the total use of electronic money (Katadata, 2019), that comes from the three largest types of transactions which are $28 \%$ retail transactions, $27 \%$ ordering online

Journal of Business and Management Review Vol. 2 No. 102021 Page 715-732

DOI: $10.47153 /$ jbmr210.2392021

*Corresponding Author

Email address: handri.mufti@yahoo.co.id 
transportation and 20\% ordering online food (Mix.co, 2019). The government also take part by targeting 8 million MSMEs (Micro, Small \& Medium Enterprises) whose already use the digital services by 2020, and soon towards cashless society through the non-cash transaction movement (Kominfo, 2019). Go-Jek as the largest provider of mobile payment in Indonesia has more than 200,000 business partners who accept payments through Go-Pay, including MSMEs partners (Tribunnews, 2018).

Many of numerous Go-Pay partners does not mean that fintech development has no barriers, one of them is the mental barrier to adopting fintech facilitated services, it means that the use of cash transactions felt to be more convenient for its ease and practice (Pulse Lab Jakarta, 2018). Furthermore, the problem from fee/commission charged to MSMEs, the insufficient aggregate from customer's demand, the inconsistency from technological and regulatory infrastructure, and the difficulties in normalizing MSMEs to pay full tax on sales also contribute to the obstruction of mobile payment-based fintech adoption (World Bank, 2016). Although it is inevitable, the fact that consumer behaviour switching to cashless payment systems will increase and exceed, or even replace cash transaction options (Bezhovski, 2016) due to the much easier, safe, efficient, and innovative payment (Usman, 2017).

To overcome this problem, the government, the entrepreneur and the community must take part in socializing the cashless society. The government develops systems and regulations as the legal law for electronic money, the entrepreneur promotes the use of electronic money by providing the tools and instruments, and the community itself start to change their cash transactions to non-cash transactions (Tazkiyyaturrohmah, 2018).

Many research on mobile payments in consumer's context through Technology Acceptance Model (TAM) approaches has been composed, such as conducted by Juhri and Dewi (2017) entitled "Trust and Acceptance of T-CASH Mobile Money in Bandung with the Technology Acceptance Model (TAM) Approach", and by Susanti (2015) entitled "The Effect of Perceived Cost, Perceived Usefulness, Perceived Risk and Perceived Trust on Mobile Banking Awareness". The study of TAM mobile payment on merchants has been conducted overseas, as in a study by Singh and Sinha (2019) entitled "How Perceived trust mediates merchant's Intention to use a mobile wallet technology", but this research is sporadically done in Indonesia.

Based on previous discussion, the purpose of the research conducted is to obtain an impact of Perceived cost on Intention to use the Go-Pay mobile payments for small merchants; describe the effect of Perceived usability on Intention to use the Go-Pay mobile payments for small merchants; explain the effect of Perceived trust on the Intention to use the Go-Pay mobile payments for small merchants and describe the effect of Perceived Customer Value Addition on Intention to use the Go-Pay mobile payments for small merchants. 


\section{Literature Review}

\section{Intention to use}

This theory is the development of The Reasoned Action Theory various parties' stated that in in the systems of management information field (Benbasat \& Barki 2007), TAM actually when it was developed was intended to provide a prediction of the behaviour of individuals who took and took advantage of the latest information technology introduced by producers (Davis 1989).

The definition of Intention to use is the tendency of individual behaviour to continuously utilize technology. The level of utilization of a technology can be measured based on the user's attitude towards the technology such as motivation to continue using it and the intention to encourage other users (Venkatesh et al., 2012). Studies related to Intention to use the technology of mobile payment have been studied for a long time, for example in studies conducted by Mallat and Tuunainen (2008), Cabanillas et al. (2016); Li (2018); and Cabanillas et al., (2018). A number of literatures suggest identifying several factors that can have an impact on technology adoption. There are various conceptual frameworks and models, such as Technology Acceptance Model (TAM), Innovation Diffusion Theory (DOI), Planned Behaviour Theory (TRA), Integrated Admission and Use of Technology Theory (UTAUT2)) and social cognitive theory (Dahlberg et al. al., 2008; Ondrus et al., 2009; Venkatesh et al., 2012). The model of the conceptual consists of some factors for measuring behavioural outcomes in the mobile payments system. A number of published studies on payments services utilizing UTAUT and TAM were reviewed by Dahlberg et al. (2015). ); From a number of studies, it was concluded that compatibility perception, with perceived ease of use as the dominating variable in giving effect, and then perceived trust and risk. Previous studies have emphasized the TAM, UTUAT2, and the adoption of other technology models urgency for merchants or customers to use technology of mobile payment. (Hayashi, 2012c; Singh, 2016; Abhishek and Hemchand, 2016; Singh and Srivastava, $\underline{2018)}$.

From the customer's point of view, there are several previous researchers who studied several aspects that affect the use of cellular payment technology, including Perceived ease of use, Perceived Customer Value Addition, social norms, trust, risk, innovation, habits, and others as a reference (Dahlberg et al., (2008); Venkatesh et al., (2012); Madan and Yadav, (2016); Singh et al., (2017). Some of those paper confirmed that Perceived ease of use, Perceived Customer Value Addition, and social norms were aspects that have an impact on consumer acceptance and technology (Barbuta et al., 2012; Oliveira et al., 2016; Cabanillas et al., 2018). On the other hand, from the merchant's point of view, it concludes that Perceived cost, Perceived trust, and condition of facilities encourage the use of cellular payment technology ( $\mathrm{Hu}$ et al., 2008; Cabanillas et al., 2016; Możdżyński, 2018). If observed, it can be seen that 
previous research has paid attention to things that distinguish between perceptions and attitudes of consumers and merchants; The researcher explained that consumers have psychological and behavioral drives related to technology, for example comfort, personal innovation, habitual norms, beliefs, a number of risks, social perceptions, and other aspects. (Abhishek and Hemchand, 2016; Madan and Yadav, 2016). Meanwhile, from the merchant side, they have more attention on the technical and functional aspects of a service that is based on technology (Cabanillas et al., 2016, Cabanillas et al., 2017; Li, 2018)

\section{Perceived cost}

Cost reduction is the main merchants' motivation to approve to online payment systems. High costs are the mai problem in merchants' approval of mobile payment technology (Mallat and Tuunainen, 2008) because merchants bear various costs when adopting the technology, and have a significant influence in using it. Also, there is an effect of Perceived costs and Perceived trust and experience on the merchant's behavioral significantly (Możdżyński, 2018). Otherwise, mobile wallet services are more preferred (Arango and Taylor, 2008) because they are more cost-effective than other services that use basic short-range communication like Near Field Communication (NFC) (Cabanillas et al., 2016). Several papers have reviewed and paid attention to several aspects, namely cost, risk, awareness, convenience, efficacy, which encourage merchant trust and intention to use a mobile wallet system (Ondrus and Pigneur, 2009; Hu et al., 2008; Możdżyński, 2018). However, only a few studies have raised UTAUT and TAM variables in the perspective of merchants in emerging markets (Singh and Srivastava, 2018).

\section{Perceived trust}

Quoted from Reichheld and Schefter, (2000), perceived trust can be defined as an important factor in adopting technology and supporting merchants to develop customer relationships which are strong. It is an emotional condition that motivates someone (individual) to believe in others, that is according to behavior to satisfaction to others. A number of studies related to technology adoption confirm the trust urgency as an instrument to improve relationships with the customers, and for increasing trust and perception of security systems (Cabanillas et al., 2018). Merchants need to understand a variety of technological innovations, which may or may not be considered useful, but fluctuating trust in the system and ultimately has an impact on the impetus to utilize technology (Morgan and Hunt, 1994; Ehrenhard et al., 2017). Hayashi and Bradford (2014) who have conducted research on mobile payments, and confirmed that the common of merchants believe that trust is a vital aspect in the use of mobile payments; A number of merchants feel sad and regret the emergence of problems related to security and privacy on the system. Merchants believe that these 
problems can reduce the trust of mobile wallet service users, both merchants and consumers.

\section{Perceived usefulness}

In technology context, the definition of perceived usefulness is what users expect in using the system to improve job performance in relation to the organization (Davis, (1989). In the system of online technology, the definition of usability is the use of technology that has benefits for users to produce certain tasks (Madan and Yadav 2016; Natarajan et al., 2017). In this case, Barbuta et al. (2012) confirmed that Perceived Customer Value Addition, together with Perceived security and scalability, have an impact on merchant behavior in accepting the system of mobile wallet. Kim et al. (2010) provides an explanation that Perceived security and usefulness have an impact on the trust and intention of merchants to take advantage of the wallet system On the other hand, for the research of Schierz et al. (2010) and Ramos de Luna et al. (2019) asserted that Perceived ease of use, Perceived usefulness, and Perceived behavior encourage a person's desire to use technology. In previous research, Perceived Customer Value Addition, and Perceived ease of use, were positioned as indicators used to assess (parameters) the behavioral intentions of the user variable (Youris and Kauffman, 2008; Koukova et al., 2008; $\underline{\text { Singh and Srivastava, 2018) }}$

\section{Perceived customer value addition}

It is the totality of benefits and experiences that can be felt or accepted by customers, according to the benefits of a product (Hayashi 2009; Lewis 2006). The definition of adding customer value in the scope of online technology is the value obtained, that can be proportional to the things paid, according to the comparatively performance and usefulness of the technology (Varki and Mark (2001).

Quoted from Lepak et al. (2007) "the relative amount of value that is subjectively achieved by the target users (or buyers) which are the focus of value creation". The subjective value shows a willingness of individual to exchange a certain amount of money for the value received. Then, the value proposition of using the service and the value perceived by the target customer (Ondrus et al., 2009). For example, offering a method that provides greater convenience and security for payment for products or services using smartphone to customers. Through the adoption or development of mobile payment solutions, merchants are able to reduce transaction fees and costs (Wong et al., 2015; Mallat \& Tuunainen, 2008).

\section{Research Hypothesis}

Hayashi and Bradford (2014) in their research confirm that the perceived cost in terms of mobile payment adoption is the second dominant factor. Small retailers believe that the mobile payment system is able to minimize costs caused by the 
existence of fraudulent modes and the occurrence of processes in each transaction. Previous studies also stated that the overall cost is the main factor that affect the merchant's adopted behaviour (Chong et al., 2010; Dwivedi et al., 2017). Both studies state that the perceived cost of a technology encourages the intention of consumers or merchants to take advantage of mobile payment services. This is because cash payments do not include any costs, consumers have an expectation that the costs of mobile payment services will be low or even without costs at all (Karnouskos and Fokus (2004). In this research, we define Perceived costs as a level which a small merchant can believe that the costs required when using the payment system will reduce his desire to use the Go-Pay payment system. We therefore argue that:

\section{H1: Perceived costs have a significant and negative effect on the intention to use mobile payment Go Pay for small merchants}

When utilizing mobile payments, transactions are transferred from consumers to retailers through a number of parties including the ecosystem: retailers, mobile manufacturers, network providers, software developers, and financial companies (Amoroso and Magnier-Watanabe, 2012; Grabner-Kräuter and Kaluscha, 2003; Hoofnagle et al., 2012). Gefen et al. (2003). Perceived trust is able to encourage a customer in their online shopping habits. A qualitative study examining the impact of attitudes on mobile payments, Dahlberg et al. 2003 in his research explains that Perceived trust is a concern. Referring to Shawn's (2014) research, Perceived trust is able to encourage a person's intention to use technology. The research results are in line with the findings of Duane et al. (2012). In this research, we define Perceived trust representing a merchant's belief that their data is safe, and that consumer payments will be properly credited to the merchants. We therefore argue that:

\section{H2: Perceived trust has a significant and positive effect on the intention to use mobile payment Go Pay for small merchants}

Davis et al. (1989) provides a definition of Perceived usefulness as the subjective possibility of potential users who use an application system to have high performance in organizational scopes. According to the definition, Davis et al (1989) and Adams, D.A (1992) found that Perceived usefulness was the main determinant of behaviour and Intention to use. Subramanian (1994) restated two measures of trust (Perceived usefulness and Perceived ease of use using a number of new data for two different technologies, and detecting Perceived usefulness, and not Perceived ease of use, which encourage behavior in technology use with Structural Equation analysis Modeling (SEM) In this research, the researcher chose the operational definition of Perceived usefulness as the level of individual confidence of small traders that using the Go-Pay payment system will be able to improve the sales performance of their stores. We therefore argue that: 


\section{H3: Perceived usefulness has a significant and positive effect on the intention to use mobile payment Go Pay for small merchants.}

The merchants prefer technology that customers find valuable and provide an overall satisfactory service. This improves the use of technology and merchants' acceptance of new technology services. In addition, a sense of comfort with the services provided, a smooth process and adequate information are a number of other important factors that affect on Perceived Customer Value Addition and the adaptation of new technologies that include payments or mobile wallets. (Gupta et al., 2017; Cabanillas et al., 2018; Xu and Du, 2018). In this research, we define Perceived Customer Value Addition as an added value for consumers which considered can increase sales transactions or services for the provided customers by merchants through the provision of the Go-Pay payment system. We therefore argue that:

H4: Perceived customer value addition has a significant and positive effect on the intention to use mobile payment Go Pay for small merchants.

\section{Method}

This research is a correlational study because the researcher intends to define the relationship between variables and problem statements (Fraenkel and Wallen, 2008; Sekaran, 2003). The method of collecting and analyzing quantitative data was conducted using a questionnaire with closed questions.

The data in this research is a primary data and a cross-sectional study with the small merchants as the research subject because some of them have used the Go-Pay payment system. The target population in this study are small merchants who use the gopay payment system. With an unknown target population. Simple random sampling is a sampling method used. A total of 120 people were taken as samples.

This research uses a number of data analyzes that include descriptive statistics, data quality tests, classical assumption tests and multiple regression analysis, and $\mathrm{t}$ tests.

\section{Validity Test}

\section{Table 1. Validity Test}

\begin{tabular}{clc}
\hline \multicolumn{1}{c}{ Variable } & \multicolumn{1}{c}{ Questions Number } & r-Value \\
\hline Perceived costs (PC) & Installation fee Mobile Payment Go-Pay is not Expensive &, 645 \\
\cline { 2 - 3 } & Go-Pay make deductions on payments from customers &, 284 \\
\cline { 2 - 3 } & No training cost needed to use Mobile Payment Go-Pay &, 756 \\
\cline { 2 - 3 } & Customer don't pay fees to use Mobile Payment Go-Pay &, 619 \\
\hline Perceived trust (PT) & I trust Go-Pay are safe and has reliable features &, 717 \\
\cline { 2 - 3 } & I trust application and transaction on Go-Pay System &, 782 \\
\hline
\end{tabular}




\begin{tabular}{|c|c|c|}
\hline Variable & Questions Number & r-Value \\
\hline & I trust my financial information and my customer are safe & 718 \\
\hline & I trust my personal information and my customer are safe & 775 \\
\hline \multirow{4}{*}{$\begin{array}{l}\text { Perceived usefulness } \\
(\mathrm{PU})\end{array}$} & Go-Pay Help me and my customers & 646 \\
\hline & Go-Pay ease to access and convenient to use & 726 \\
\hline & Go-Pay improves my performance & ,724 \\
\hline & Go-Pay speeds up my customer's payment process & 740 \\
\hline \multirow{4}{*}{$\begin{array}{l}\text { Perceived Customer } \\
\text { Value Addition } \\
\text { (PCVA) }\end{array}$} & Go-Pay allows me to offer several benefits to customers & 654 \\
\hline & Go-Pay make a great experience for my customers & 643 \\
\hline & Go-Pay add value for me and my customers &, 595 \\
\hline & Go-Pay helps me improve relationships with customers & 648 \\
\hline \multirow{4}{*}{$\begin{array}{l}\text { Intention to use } \\
\text { (ITU) }\end{array}$} & I will increase the use of Go-Pay in the future & 703 \\
\hline & I use Go-Pay in the future & 741 \\
\hline & I will always Go-Pay & 763 \\
\hline & I have plan to use Go-Pay everyday & ,758 \\
\hline
\end{tabular}

Note: $\mathrm{R}$ table at $\mathrm{\alpha}=5 \%$ with $\mathrm{N}=120$ is 0.1779

Validity testing is done using SPSS. The Validity Test showed that all variable questions have r-count greater than r-table (0.1779) Thus, conclusions can be drawn that are declared valid from all the questions in the questionnaire.

\section{Reliability Test}

Table 2. Reliability Test

\begin{tabular}{lc}
\hline \multicolumn{1}{c}{ Variable } & Cronbach's Alpha \\
\hline Perceived costs (PC) & 0,319 \\
Perceived trust (PT) & 0,738 \\
Perceived usefulness (PU) & 0,671 \\
Perceived Customer Value Addition (PCVA) & 0,507 \\
Intention to use (ITU) & 0,727 \\
\hline
\end{tabular}

Note: $r$-table at $\alpha=5 \%$ with $\mathrm{N}=120$ is 0.1779

To determine the data reliability tested with the SPSS program. Then results can be seen that the r-count of all variables $>$ r-table $(0.1779)$, the conclusion was that all variables passed the reliability test

\section{Regression Analysis}

Multiple linear regression analysis is a techniques that used in this study. In this study are Perceived costs (PC), Perceived trust (PT), Perceived usefulness (PU), \& the Perceived Customer Value Addition (PCVA) are the independent variables, while the dependent variable is the Intention to use (ITU). Linear regression analysis has a formula:

$$
Y=B_{0}+B_{1} X_{1}+B_{2} X_{2}+B_{3} X_{3}+B_{4} X_{4}+e
$$


Information $=\mathrm{Y}$ : Intention to use $(\mathrm{ITU}), \mathrm{B}_{0}$ : Constants, $\mathbf{X}_{\mathbf{1}}$ : Perceived costs $(\mathrm{PC}), \mathbf{X}_{\mathbf{2}}$ : Perceived trust (PT), $\mathbf{X}_{\mathbf{3}}$ : Perceived usefulness (PU), $\mathbf{X}_{4}$ : Perceived Customer Value Addition (PCVA), $\mathbf{B}_{1}$ : Variable Regression Coefficient Perceived costs (PC), $\mathbf{B}_{2}$ : Variable Regression Coefficient Perceived trust (PT), $\mathbf{B}_{3}$ : Variable Regression Coefficient Perceived usefulness (PU), B4: Variable Regression Coefficient Perceived Customer Value Addition (PCVA), e: Error Level.

\section{T Test}

The use of $t$ test in order to detect the influence of one independent variable individually in explaining the dependent variable variation (Ghozali, (2012). Partial effect was tested by t-test. Criteria in determining the acceptance or rejection of the hypothesis, using the following criteria: If $\mathrm{t}$-count $>\mathrm{t}$-table and $\operatorname{sig}<0.05$, then $\mathrm{H} 0$ is rejected and $\mathrm{H} 1$ is accepted. If $\mathrm{t}$-count $<\mathrm{t}$-table, and sig $>0.05$, then $\mathrm{H} 0$ is accepted and $\mathrm{H} 1$ is rejected.

\section{Result and Discussion}

\section{Classical Assumption Test}

Table 3. Classical Assumption Test

\begin{tabular}{clccccc}
\hline No. & \multicolumn{2}{c}{ Variable } & Normality & \multicolumn{2}{c}{ Multicollinearity } & Heteroscedasticity \\
Independent & Dependent & Sig & Tol. & VIF & Sig. (two tailed) \\
\hline 1 & $\begin{array}{l}\text { Perceived Cost (PC) } \\
\text { Perceived Trust }\end{array}$ & & 0,965 & 1,037 & 0,055 \\
2 & $\begin{array}{l}\text { (PT) } \\
\text { Intention }\end{array}$ & 0,200 & 0,954 & 1,097 & 0,339 \\
3 & $\begin{array}{l}\text { Perceived } \\
\text { Usefulness (PU) }\end{array}$ & To Use & & & & 0,048 \\
4 & $\begin{array}{l}\text { Perceived customer } \\
\text { value added }\end{array}$ & & 0,904 & 1,106 & 0,075 \\
\hline
\end{tabular}

Normality testing is intended to ensure the dependent variable and the independent variable have a normal distribution that in the regression model. Kolmogorov Smirnov was chosen to test the normality of the data. The criteria if the value of sig. $>0.05$, it is concluded that the distribution of the data is normal. Referring to data processing results, the value of sig. $0.200>0.05$, which means that the data is distributed in normal way so that it passes the normality test. The Multicolinearity test was showed that all variables do not have multicollinearity based on the provisions of the Tolerance value is more than 0.10 and the VIF value more than 10. In accordance with the results of data processing, the significance value of all independent variables is greater than 0.05 . Therefore, it is certain that the independent variable does not occur heteroscedasticity and fulfill the preresquities for the classical assumption test. 


\section{T test and Multiple Linear Regression Analysis}

The t-test was run to detect whether each independent variable had a significant impact on dependent variable. The data processing results are:

\begin{tabular}{|c|c|c|c|c|c|c|}
\hline & \multirow[b]{2}{*}{ Model } & \multicolumn{2}{|c|}{$\begin{array}{l}\text { Unstandardized } \\
\text { Coefficients }\end{array}$} & \multirow{2}{*}{$\begin{array}{c}\text { Standardized } \\
\text { Coefficients } \\
\text { Beta }\end{array}$} & \multirow[b]{2}{*}{$\mathbf{t}$} & \multirow[b]{2}{*}{ Sig. } \\
\hline & & $\mathrm{B}$ & Std. Error & & & \\
\hline \multirow[t]{5}{*}{1} & (Constant) & .004 & .003 & & 1.492 & .138 \\
\hline & $\mathrm{PC}$ & .392 & .292 & .116 & 1.994 & .002 \\
\hline & PT & .449 & .170 & .235 & 2.642 & .009 \\
\hline & PU & -.171 & .212 & -.070 & -.807 & .421 \\
\hline & PCVA & .496 & .168 & .265 & 2.963 & .004 \\
\hline
\end{tabular}

Referring to the results of data processing, then a multiple linear regression equation model can be made, based on the beta value of Unstandardized Coefficients:

$$
Y=0,004+0,392 X_{1}+0,449 X_{2}-0,171 X_{3}+0,496 X_{4}+e
$$

A constant of 0.004, it means that if Perceived costs, Perceived trust, Perceived usefulness and Perceived customer value added do not exist or the value is 0 , then the Intention to use the Go-Pay payment system on small merchants is 0.004

The regression coefficient of Perceived costs (PC) variable is 0.392, it means that if Perceived costs are increased by 1 unit, then the merchant's Intention to use the GoPay payment system will increase by 0.392 units. Between Perceived cost and Intention to use, there is a direct relationship, which means the coefficient is positive

The regression coefficient of the Perceived trust (PT) variable is 0.449 , this means that if the Perceived trust increases by 1 unit, it will encourage an increase in the Intention to use Go-Pay payments system for small traders by 0.449 units. The value of the coefficient is positive, meaning that the direction of the relationship between the two variables is directly proportional

The regression coefficient value for the Perceived usefulness (PU) is negative, which is -0.171 , means that if the Perceived usefulness increases by 1 unit, it will encourage a decrease in Intention to use the Go-Pay payments system for small traders by 0.171 units. The regression coefficient is negative, meaning that the relationship between the two variables is inversely proportional.

Furthermore, Perceived customer value added (PCVA) has the regression coefficient of 0.496 means that if Perceived usefulness increases by 1 unit, the Intention to use Go-Pay payments system for small traders will be pushed up by 0.496 units. The 
coefficient is positive, meaning that the relationship between the both variables is directly proportional.

\section{Discussion}

The effect of Perceived costs on Intention to Use

Referring to the test data, the $t$ value for PC was $1.994>t$ table $(1.994>1.98063)$ and sig < $0.05(0.002<0.05)$. With this result, it can be stated that the PC variable is able to have an impact on ITU for small merchants. The conclusion of this analysis strengthens Phonthanukitithaworn et. al (2016) study, which concluded that the fees received have been identified as a major obstacle to efforts to absorb the next m-payment services. Certain Mobile payment cost, like transaction cost, new headset cost, subscription costs, then access of communication, all contributed to the increase in additional costs associated with the use of technology services. (Luarn \& Lin, 2005; Cheong \& Park, 2005; Wu \& Wang, 2005; Tsu Wei et al., 2009; Lu et al., 2011; Keramati et al., 2012). Based on the analysis of several studies, it was found that there was a real impact of PCs on the behavioral intentions of current users to take advantage of m-payment services. Moreover, it can be concluded that when small traders think about the cost of the mobile payment service such as installation fee, training cost and fee of using, it would impact their intention to use Go-Pay Mobile Payment service.

\section{The effect of Perceived Trust on Intention to Use}

From the results of the $t$-test, it is found that the $t$-value for PT is $2.642>t$-table $(2.642$ $>1,98063)$ and sig $>0,05(0,009<0,05)$. The PT variable in this study can be concluded to have an influence on ITU for Small merchants. The results of this study are supported by the statement of Singh \& Sinha. (2020). Shaw (2014) stated that trust is estimated on the certainty an individual shows on the value and security of an innovation. This means that mobile wallets are preferred whenever they can be useful, reliable, and without fraud or error in their payment transactions. (Hayashi and Bradford, 2014; Cabanillas et al., 2018; Verkijika, 2018).

\section{The effect of Perceived usefulness on Intention to Use}

From the t-test, it was found that the $\mathrm{t}$-value for PU is $-0.807<\mathrm{t}$-table $(-0.807<$ $1.98063)$ and sig $<0.05(0,421>0,05)$. Thus, it can be concluded that small merchants from ITU are influenced by the PU variable in this study. These results also strengthen the results of previous studies conducted by Sun \& Zhang, (2006); Kusumo, (2010); Malhotra \& Dash, (2011); and Gunawan, (2014), where the perceived usefulness, in this case Go-pay mobile payment, is easily accessible, improves performance, and speeds up the payment process can increase intention to use, especially among small merchants. On the other hand, it can be said that the perceived usefulness of Go-Pay Mobile Payment can encourage Intention to use Go-pay Mobile payment technology. 
From the t-test, it was found that the $t$-value for PCVA is $2.963>t$-table $(2.963>$ $1.98063)$ and sig $<0.05(0,004<0,05)$. Thus, it can be concluded that small merchants from ITU are influenced by the PCVA variable in this study. This study is in line with that of Reichheld and Schefter (2000); they get the perceived customer value addition determines intention to use a technology (Hayashi, 2009; Hayashi, 2012a; Hayashi 2012b). The adoption and success of new technologies is considered by small merchants as the worth added services of an innovation. Lundberg (2016) stated as for what can be measured through low service fees, data control, reward points and cashback, and there is also operability and flexibility.

\section{Conclusion}

The conclusion of this research is to explain how the variables of Perceived cost, Perceived trust, Perceived usefulness, and Perceived Customer Value Addition influence the dependent variable of Intention to use the Go-Pay payment system.

Showed that Perceived trust has a positive and significant influence towards Intention to use the Go-Pay payment system are the result on this research. This confirms the analysis of Shawn (2014) and Duane et al. (2012) stated that trust influences the Intention to use.

Otherwise, the results this research showed had a positive and significant influence towards Intention to use the Go-Pay payment system from Perceived Customer Value Addition. This confirms the research conducted by Gupta et al., (2017), Cabanillas et al., (2018) and $\mathrm{Xu}$ and $\mathrm{Du},(2018)$ that on the adoption of new technologies including payments or mobile wallets, service convenience, smooth processing, \& information feasibility are some of the important factors that affect Perceived Customer Value Addition.

In this research, it can be investigated that the majority $(68 \%)$ of small merchants who use the Go-Pay system are in the age range of 20-38 (Gen Y). When inspected from the system, most of them (70\%) have used it for more than 3 months. Besides, another interesting thing revealed that most of the respondents use other payment systems besides Go-Pay (62\%). The other payment systems used are OVO, I sell, Ottopay, Dana, Jakone, and Tunaikita.

This study has limitations, namely that is conducted only on small merchants using only the Go-Pay mobile payment, so the obtained perception is limited only to the GoPay payment system. Furthermore, there are many other mobile payment systems such as OVO, DANA, AKULAKU, OTTOPAY, JAKONE and TUNAIKITA. Further research is expected to expand the scope of this research. 


\section{References}

Abhishek, A., \& Hemchand, S. (2016). Adoption of sensor based communication for Mobile Marketing in India. Journal of Indian Business Research, 8(1), 65-76. https://doi.org/10.1108/jibr-08-2015-0091

Adams, D. A., Nelson, R. R., \& Todd, P. A. (1992). Perceived usefulness, ease of use, and usage of information technology: A replication. MIS Quarterly, 16(2), 227. https:// doi.org/10.2307/249577

Amoroso, D. L., \& Magnier-Watanabe, R. (2012). Building a research model for mobile wallet consumer adoption: The case of Mobile Suica in Japan. Journal of Theoretical and Applied Electronic Commerce Research, 7(1), 13-14. https://doi.org/10.4067/s071818762012000100008

Angelina, M. et.all. (2018). Menggali potensi teknologi finansial: Inklusi keuangan untuk usaha mikro di Indonesia. Retrieved from https://pulselabjakarta.org/assets/ uploadworks / 2019-01-30-04-19-04.pdf

Arango, C., \& Taylor, V. (2008). Merchant Acceptance, Costs, and Perceptions of Retail Payments: A Canadian Survey. Retrieved from https://www.bankofcanada.ca/wpcontent/uploads/2010/01/dp08-12.pdf.

Au, Y. A., \& Kauffman, R. J. (2008). The economics of mobile payments: Understanding stakeholder issues for an emerging financial technology application. Electronic Commerce Research and Applications, 7(2), 141-164. https://doi.org/10.1016/j.elerap.2006.12.004

Barbuta, I. et.all. (2012). Mobile payments guide 2012: Insights in the worldwide mobile financial service market. The Paypers BV, March, 2012. Retrieved from http://ibfsinc.com/uploads/Mobile_Payments_Market_Guide_2012.pdf

Benbasat, I., \& Barki, H. (2007). Quo Vadis Tam? Journal of the Association for Information Systems, 8(4), 211-218. https:// doi.org/10.17705/1jais.00126

Bezhovski, Z. (n.d.). The Future of the Mobile Payment as Electronic Payment System. Retrieved from https://www.iiste.org/Journals/index.php/EJBM/article/view/29473

Cabanillas, F., Marinkovic, V., Ramos de Luna, I., \& Kalinic, Z. (2018). Predicting the determinants of Mobile Payment Acceptance: A hybrid sem-neural network approach. Technological Forecasting and Social Change, 129, 117-130. https:// doi.org/10.1016/j.techfore.2017.12.015

Cabanillas, L. F., Leiva, F.M \& Fernández, J.S., (2017). Examining Merchants' Refusal to Adopt Mobile Payment Systems in Spain. Published in Book in Smartphones from an Applied Research Perspective https://10.5772/intechopen.70284.

Cabanillas, L. F., Slade, E., \& Dwivedi, Y. (2016). Time for a different perspective: a preliminary investigation of barriers of merchants' adoption of mobile payments. In: Proceedings of the 22nd Americas Conference on Information Systems, San Diego.

Cheong, J. H., \& Park, M. C. (2005). Mobile internet acceptance in Korea. Internet Research, 15(2), 125-140. https:/ / doi.org/10.1108/10662240510590324

Chong, A. Y. L., Ooi, K. B., Lin, B., \& Tan, B. I. (2010). Online banking adoption: An empirical analysis. International Journal of Bank Marketing, 28(4), 267-287. https:/ / doi.org/10.1108 $\angle 02652321011054963$

Content writer. (2018). GO-PAY PAY DAY Kasih Cashback 50\%! Ini List Merchant-nya. Retrieved from https://www.tribunnews.com/travel/2018/11/27/go-pay-pay-daykasih-cashback-50-ini-list-merchant-nya 
Content writer. (2019). Begini Tren Penggunaan Uang Elektronik konsumen Indonesia. MIX Marcomm. (2019, July 15). Retrieved from https://mix.co.id/marcomm/ newstrend/ begini-tren-penggunaan-uang-elektronik-konsumen-indonesia/.

Content writer. (2019). Berapa transaksi Uang Elektronik di Indonesia? Databoks. (n.d.). Retrieved October 27, 2021, from https://databoks.katadata.co.id/datapublish/2019 $\angle 11 / 07 /$ berapa-transaksi-uang-elektronik-di-indonesia.

Dahlberg, T., Mallat, N., Ondrus, J., Zmijewska, A., (2008). Past, present and future of mobile payments research: $\{\mathrm{A}\}$ literature review. Electron. Commer. Res. Appl. 7 (2), 165-181. https://10.1016/j.elerap.2007.02.001

Dahlberg, Tomi \& Guo, Jie \& Ondrus, Jan. (2015). A critical review of mobile payment research. Electronic Commerce Research and Applications. $14 . \quad 265-284$. https://10.1016/j.elerap.2015.07.006

Davis, F. D., Bagozzi, R. P., \& Warshaw, P. R. (1989). User Acceptance of Computer Technology: A Comparison of Two Theoretical Models. Management Science,35(8), 982-1003. https://doi.org/10.1287/mnsc.35.8.982.

De Luna, I. R., Liébana-Cabanillas, F., Sánchez-Fernández, J., \& Muñoz-Leiva, F. (2019). Mobile payment is not all the same: The adoption of mobile payment systems depending on the technology applied. Technological Forecasting and Social Change, 146, 931-944. https://doi.org/10.1016/j.techfore.2018.09.018

Dina, S. (2017). Pemerintah Mau 8 Juta UMKM Pakai Layanan Pembayaran Digital pada 2020. Retrieved from https://kominfo.go.id/content/detail/12092/pemerintah-mau-8-jutaumkm-pakai-layanan-pembayaran-digital-pada-2020/0/sorotan_media

Duane, A., O’Reilly, P., \& Andreev, P. (2014). Realising M-Payments: Modelling consumers' willingness to M-pay using Smart Phones. Behaviour and Information Technology, 33(4), 318334. https:// doi.org/10.1080/0144929X.2012.745608

Dwivedi, Y. K. et.all. (2017). An empirical validation of a unified model of electronic government adoption (UMEGA). Government Information Quarterly, 34(2), 211-230. https://doi.org/10.1016/ j.giq.2017.03.001

Ehrenhard, M., Wijnhoven, F., van den Broek, T., \& Zinck Stagno, M. (2017). Unlocking how start-ups create business value with mobile applications: Development of an app-enabled Business Innovation Cycle. Technological Forecasting and Social Change, 115, 26-36. https:// doi.org/10.1016/j.techfore.2016.09.011

Fraenkel, J., Wallen, N., \& Hyun, H. (2012). Correlational Research. In How to design and evaluate research in Education (pp. 331-357). McGraw-Hill.

Franedya, R. (2019, February 11). Terungkap! Transaksi GoPay di 2018 Tembus Rp 87 T. Retrieved from https://www.cnbcindonesia.com/tech/20190211103125-37-54742/ terungkap-transaksi-gopay-di-2018-tembus-rp-87-t

Gefen, D., Karahanna, E., \& Straub, D. (2003). Trust and TAM in online shopping: An integrated model. MIS Quarterly, 27(1), 51. https://doi.org/10.2307/30036519

Ghozali, I. (2012). Aplikasi Analisis Multivariate dengan Program IBM SPSS. Yogyakarta: Universitas Diponegoro.

Gunawan, A. (2014). APLIKASI technology acceptance model Pada Minat Nasabah untuk Menggunakan internet banking. Nominal, Barometer Riset Akuntansi Dan Manajemen, 3(2). https://doi.org/10.21831/nominal.v3i2.2695

Gupta, S., Yun, H., Xu, H., \& Kim, H.-W. (2017). An exploratory study on mobile banking adoption in Indian Metropolitan and urban areas: A scenario-based experiment. 
Information Technology for Development, 23(1), 127-152. https:// doi.org/10.1080/02681102.2016.1233855

Hayashi, F., \& Bradford, T. (2012). Mobile Payments: Merchants' Perspectives I. PAYMENT ENVIRONMENT AND MOBILE PAYMENT TECHNOLOGIES, 33-58. Retrieved from https://www.kansascityfed.org/XdNVZ/publicat/econrev/pdf/14q2HayashiBradford.pdf

Hoofnagle, C. J., Urban, J. M., \& Li, S. (2012). Mobile payments: Consumer Benefits \& New Privacy Concerns. SSRN Electronic Journal. https://doi.org/10.2139/ssrn.2045580

$\mathrm{Hu}, \mathrm{X} ., \mathrm{Li}, \mathrm{W} .$, \& Hu, Q. (2008). Are mobile payment and banking the Killer Apps for Mobile Commerce? Proceedings of the 41st Annual Hawaii International Conference on System Sciences (HICSS 2008). https:/ / doi.org/10.1109/hicss.2008.69

Juhri, K and Dewi, C.K. (2017). Kepercayaan dan penerimaan layanan mobile money T-cash di Bandung dengan pendekatan Technology Acceptance Model (TAM). Jurnal Pro Bisnis, 1(2), 10. Retrieved from http://ejournal.amikompurwokerto.ac.id/index.php/ probisnis/article/view/503

Kaluscha, E. A., \& Grabner-Kräuter, S. (2003). Conference: Proceedings of the 8th European Conference on Pattern Languages of Programms (EuroPLoP '2003). In Patterns for Consumer Trust in Electronic Commerce. Irsee; dblp.

Karnouskos, S. (2004). Mobile payment: A journey through existing procedures and standardization initiatives. IEEE Communications Surveys $\mathcal{E}$ Tutorials, 6(4), 44-66. https://doi.org/10.1109/comst.2004.5342298

Keramati, A., Taeb, R., Larijani, A. M., \& Mojir, navid. (2012). A combinative model of behavioural and technical factors affecting 'mobile'-payment services adoption: An empirical study. The Service Industries Journal, 32(9), 1489-1504. https://doi.org/10.1080/02642069.2011.552716

Kim, C., Tao, W., Shin, N., \& Kim, K.-S. (2010). An empirical study of customers' perceptions of security and trust in e-payment systems. Electronic Commerce Research and Applications, 9(1), 84-95. https://doi.org/10.1016/j.elerap.2009.04.014

Kominfo, P. (n.d.). Pemerintah Mau 8 Juta UMKM pakai Layanan pembayaran digital pada 2020. Website Resmi Kementerian Komunikasi dan Informatika RI. Retrieved from https://kominfo.go.id/content/detail/12092/pemerintah-mau-8-juta-umkm-pakailayanan-pembayaran-digital-pada-2020/0/sorotan_media.

Koukova, N., Kannan, P., \& Ratchford, B. (2008). Product form bundling: Implications for marketing digital products. Journal of Retailing, 84(2), 181-194. https://doi.org/10.1016/j.jretai.2008.04.001

Kusumo, H.C. 2010. Analisis penerimaan Mobile Banking (M-Banking) dengan kerumitan (Complexity) sebagai variabel eksternal dengan menggunakan Technology Acceptance Model (TAM). Skripsi. Fakultas Ekonomi. Universitas Sebelas Maret. Surakarta. http://eprints.uns.ac.id/7838/1/170451611201112241.pdf.

Lepak, D. P., Smith, K. G., \& Taylor, M. S. (2007). Value creation and value capture: A multilevel perspective. Academy of Management Review, 32(1), 180-194. https://doi.org/10.5465/amr.2007.23464011

Lewis, M. (2006). Customer Acquisition Promotions and customer asset value. Journal of Marketing Research, 43(2), 195-203. https://doi.org/10.1509/jmkr.43.2.195 
Li, Y., 2018. The strategic decision on mobile payment: a study on Merchantsâ€ ${ }^{\mathrm{TM}}$ adoption.In: Proceedings of the Conference Adoption and Diffusion of Information Technology (SIGADIT), AMCIS 2018, USA.

Lingga, H. (2019, February 21). Dahsyat! Bisnis Mobile Payment di Indonesia Dahsyat. Retrieved from https://www.wartaekonomi.co.id/read216524/dahsyat-bisnis-mobilepayment-di-indonesia-dahsyat.html

Lu, Y., Yang, S., Chau, P. Y. K., \& Cao, Y. (2011). Dynamics between the Trust Transfer Process and intention to use mobile payment services: A cross-environment perspective. Information \& Management, 48(8), 393-403. https://doi.org/10.1016/j.im.2011.09.006

Luarn, P., \& Lin, H.-H. (2005). Toward an understanding of the behavioral intention to use mobile banking. Computers in Human Behavior, 21(6), 873-891. https://doi.org/10.1016/j.chb.2004.03.003

Lundberg, D. (2016). When do farmers adopt New Technology. LinkedIn. Retrieved from https://www.linkedin.com/pulse/when-do-farmers-adopt-new-technology-davelundberg/.

Madan, K., \& Yadav, R. (2016). Behavioural intention to adopt Mobile Wallet: A developing country perspective. Journal of Indian Business Research, 8(3), 227-244. https://doi.org/10.1108/jibr-10-2015-0112

Malhotra, N. K., \& Dash, S. (2011). Marketing research: An applied orientation. New Delhi: Pearson.

Mallat, \& Tuunainen. (2008). Exploring Merchant Adoption of Mobile Payment Systems: An Empirical Study. E-Service Journal, 6(2), 24. https://doi.org/10.2979/esj.2008.6.2.24

Morgan, R. M., \& Hunt, S. D. (1994). The commitment-trust theory of Relationship Marketing. Journal of Marketing, 58(3), 20. https:// doi.org/10.2307/1252308

Możdżyński, D. (2018). Acceptance of Payment Systems from the Perspective of Merchants. Information Systems in Management, 7, 16-34. https:// doi.org/10.22630/ISIM.2018.7.1.3

Natarajan, T., Balasubramanian, S. A., \& Kasilingam, D. L. (2017). Understanding the intention to use mobile shopping applications and its influence on price sensitivity. Journal of Retailing and Consumer Services, 37, 8-22. https://doi.org/10.1016/ j.jretconser.2017.02.010

Oliveira, T. et.all. (2016). Mobile payment: Understanding the determinants of customer adoption and intention to recommend the technology. Computers in Human Behavior, 61, 404-414. https:// doi.org/10.1016/j.chb.2016.03.030

Ondrus, J., Lyytinen, K., \& Pigneur, Y. (2009). Why mobile payments fail? towards a dynamic and multi-perspective explanation. 2009 42nd Hawaii International Conference on System Sciences. https:// doi.org/10.1109/hicss.2009.510

Phonthanukitithaworn, C., Sellitto, C., \& Fong, M. W. (2016). A comparative study of current and potential users of mobile payment services. SAGE Open, 6(4), 215824401667539. https://doi.org/10.1177/2158244016675397

Reichheld, F. \& Schefter, P.. (2000). E-Loyalty: Your Secret Weapon on the Web. Harvard Business Review. 78. Retrieved from https://hbr.org/2000/07/e-loyalty-your-secretweapon-on-the-web

Schierz, P. G., Schilke, O., \& Wirtz, B. W. (2010). Understanding consumer acceptance of mobile payment services: An empirical analysis. Electronic Commerce Research and Applications, 9(3), 209-216. https://doi.org/10.1016/j.elerap.2009.07.005 
Sekaran, U. (2003) Research Methods for Business: A Skill-Building Approach. 4th Edition, John Wiley \& Sons, New York

Setyowati, D. (2019, February 22). Dua riset sebut Go-Pay dominasi Pasar Pembayaran digital di Indonesia. Retrieved from https://katadata.co.id/berita/2019/01/22/dua-riset-sebutgo-pay-dominasi-pasar-pembayaran-digital-di-indonesia

Shaw, N. (2014). The mediating influence of trust in the adoption of the mobile wallet. Journal of Retailing and Consumer Services, 21(4), 449-459. https://doi.org/10.1016/j.jretconser. 2014.03.008

Singh, N., \& Sinha, N. (2020). How perceived trust mediates merchant's intention to use a mobile wallet technology. Journal of Retailing and Consumer Services, 52, 101894. https://doi.org/10.1016/i.jretconser.2019.101894

Singh, S., \&amp; Srivastava, R. K. (2018). Predicting the intention to use mobile banking in India. International Journal of Bank Marketing, 36(2), 357-378. https://doi.org/10.1108/ijbm-12-2016-0186

Subramanian, G. H. (1994). A Replication of Perceived usefulness and Perceived Ease of Use Measurement. Decision Sciences, 25(5-6), 863-874. http://doi.org10.1111/j.15405915.1994.tb01873.x

Sun, H., \& Zhang, P. (2006). The role of moderating factors in user technology acceptance. International Journal of Human Computer Studies, 64(2), 53-78. https://doi.org/10.1016/j.ijhcs.2005.04.013

Susanti, A. (2015, January 26). Pengaruh persepsi kegunaan, persepsi kemudahan, persepsi risiko dan persepsi kepercayaan terhadap minat menggunakan mobile banking. Retrieved from http:/ / digilib.uin-suka.ac.id/15945/

Tazkiyyaturrohmah, Rifqy. (2018). c. Muslim Heritage. $3 . \quad 23$. https://10.21154/muslimheritage.v3i1.1240.

Teima, G. et.all. (2016). Innovation in Electronic Payment Adoption: The case of small retailers. Worldbank.org. Retrieved October 27, 2021, from http://documents1.worldbank.org /curated/en/765851467037506667/pdf/106633-WP-PUBLIC-Innovative-SolutionsAccelerate-Adoption-Electronic-Payments-Merchants-report-2016.pdf.

Tsu Wei, T., Marthandan, G., Yee - Loong Chong, A., Ooi, K. B., \& Arumugam, S. (2009). What drives Malaysian $\mathrm{m}$ - commerce adoption? an empirical analysis. Industrial Management \& Data Systems, 109(3), 370 - 388. https://doi.org/10.1108/02635570910939399

Usman, R. (2017). Karakteristik Uang Elektronik dalam Sistem Pembayaran. Yuridika. 32. 134. https://10.20473/ydk.v32i1.4431.

Varki, S., \& Colgate, M. (2001). The role of Price Perceptions in an integrated model of behavioral intentions. Journal of Service Research, 3(3), 232-240. https://doi.org/10.1177/109467050133004

Venkatesh, V., Thong, J. Y. L., \& Xu, X. (2012). Consumer acceptance and use of information technology: Extending the unified theory of acceptance and use of Technology. MIS Quarterly, 36(1), 157-178. https:// doi.org/10.2307/41410412

Verkijika, S. F. (2018). Factors influencing the adoption of mobile commerce applications in Cameroon. Telematics and Informatics, 35(6), 1665-1674. https://doi.org/10.1016/j.tele.2018.04.012

Wong, C.-H., Tan, G. W.-H., Tan, B.-I., \& Ooi, K.-B. (2015). Mobile Advertising: The changing landscape of the advertising industry. Telematics and Informatics, 32(4), 720-734. https://doi.org/10.1016/j.tele.2015.03.003 
Wu, J.-H., \& Wang, S.-C. (2005). What drives mobile commerce? Information \& Management, 42(5), 719-729. https:// doi.org/10.1016/j.im.2004.07.001

Wulandari, D. (2019, Juli 15). Begini tren penggunaan uang elektronik konsumen Indonesia. Retrieved from https://mix.co.id/marcomm/news-trend/begini-tren-penggunaan-uangelektronik-konsumen-indonesia/

Xu, F., \& Du, J. T. (2018). Factors influencing users' satisfaction and loyalty to digital libraries in Chinese universities. Computers in Human Behavior, 83, 64-72. https://doi.org/10.1016/j.chb.2018.01.029 